\title{
Mutations in the NSD1 gene in patients with Sotos syndrome associate with endocrine and paracrine alterations in the IGF system
}

\author{
L de Boer ${ }^{1}$, H A van Duyvenvoorde ${ }^{1}$, E C Willemstein-van Hove ${ }^{2}$, C M Hoogerbrugge ${ }^{4}$ J Van Doorn ${ }^{4}$, J A Maassen ${ }^{2}$,
} M Karperien ${ }^{1,3}$ and J M Wit ${ }^{1}$

${ }^{1}$ Department of Pediatrics, ${ }^{2}$ Department of Molecular Cell Biology, ${ }^{3}$ Department of Endocrinology \& Metabolic Diseases, Leiden University Medical Center, Leiden and ${ }^{4}$ Department of Metabolic and Endocrine Diseases, University Medical Center/Wilhelmina Children's Hospital, Utrecht, The Netherlands

(Correspondence should be addressed to J M Wit; Email: jwit@lumc.nl)

\begin{abstract}
Objective: To investigate the effect of nuclear receptor Su-var, 3-9, enhancer of zeste, trithorax (SET) domain-containing protein 1 (NSD1) gene alteration in patients with Sotos syndrome on plasma IGFs and IGF-binding proteins (IGFBPs), as well as on the IGF/IGFBP system activity at the tissue level. Design: Twenty-nine patients suspected of Sotos syndrome were divided into two groups: patients with heterozygous deletions or mutations in the NSD1 gene $\left(\mathrm{NSD}^{+/-}\right)(n=11)$ and subjects without $\left(\mathrm{NSD}^{+/+}\right)(n=18)$. Plasma samples $(n=29)$ and skin fibroblasts $(n=23)$ were obtained. The results of both groups were compared and related to reference values.

Methods: IGF-I, IGF-II, IGFBP-2, IGFBP-3, IGFBP-4 and IGFBP-6 levels were determined by RIAs. The mitogenic response of fibroblasts to IGFs was investigated by $\left[\right.$ methyl- $\left.{ }^{3} \mathrm{H}\right]$ thymidine incorporation. IGFBP-3 levels in the culture media were measured by RIA. IGFBP-3 mRNA expression was determined by real time RT-PCR.

Results: $\mathrm{NSD}^{+/-}$patients showed significantly altered levels of IGF-I (mean -1.2 SDS), IGF-II $(-1.2)$, IGFBP-3 $(-1.7)$, IGFBP-4 $(-0.4)$, IGFBP-2 $(+0.8)$ and IGFBP-6 $(+1.5)$. The NSD1 ${ }^{+/+}$ patients did not differ from the reference, with the exception of the mean IGFBP-3 level $(-1.3)$. Basal proliferation and mitogenic response to IGFs was diminished in NSD ${ }^{+/}$fibroblasts compared with $\mathrm{NSD1}^{+/+}$(basal, $P=0.02$; IGF-I, $P<0.001$; IGF-II, $P=0.02$ ). Compared with control fibroblasts, only the mitogenic response was diminished (basal, $P=0.07$; IGF-I, $P=0.04$; IGF-II, $P=0.04)$. A trend of higher IGFBP-3 secretion after IGF-I stimulation $(P=0.09)$ and $3.5-5$ times higher mRNA expression of IGFBP-3 in basal conditions was found in NSD1 ${ }^{+/-}$fibroblasts in comparison to controls.

Conclusions: $\mathrm{NSD}^{+/-}$patients show endocrine and paracrine changes in the IGF system. These changes may contribute to the abnormal growth pattern.
\end{abstract}

European Journal of Endocrinology 151 333-341

\section{Introduction}

Sotos syndrome (cerebral gigantism; OMIM 117550) is an overgrowth syndrome that was first described in 1964 (1). Patients show such typical facial characteristics as frontal bossing, dolichocephaly, high hairline, prominent chin and antimongoloid slant of palpebral fissures. Other important clinical features are overgrowth with large size at birth, rapid growth in the first 4 years (2) and tall stature in childhood, advanced bone age, macrocephaly, mental retardation and delayed motor development $(1,3)$. Heterozygous deletions and inactivating mutations involving the gene for nuclear receptor Su-var, 3-9, enhancer of zeste, trithorax (SET) domain-containing protein 1 (NSD1) have been proposed as a major determinant in the aetiology of Sotos syndrome (4-7).

In Sotos syndrome prenatal overgrowth is often present. Both insulin-like growth factors (IGFs) I and II are important growth factors in utero. They exert their growth-promoting effects at both the endocrine and para-/autocrine levels $(8,9)$. Mice carrying null mutations for the IGF-I, IGF-II or IGF-I receptor (IGF-IR) genes are smaller at birth $(10,11)$. In humans, cases of intrauterine growth retardation have been reported in association with a homozygous partial deletion of the IGF-I gene leading to total IGF-I deficiency (12) and more recently with absence of one copy of the IGF-IR gene (13). The latter study also describes a patient with three copies of the IGF-IR 
gene, showing intrauterine and postnatal overgrowth and a head circumference on the 98th percentile at birth. This patient showed a normal serum IGF-I level with increased cell proliferation and response to IGF-I by skin fibroblasts. The Sotos-like phenotype of this patient would suggest that changes in the IGF system may contribute to the abnormal growth pattern in Sotos syndrome.

In studies of patients clinically suspected of Sotos syndrome, biochemical growth parameters such as growth hormone $(14-17)$ and somatomedin activity (biological activity of IGFs) $(2,16,18-21)$ have been measured. Levels were in the normal range for most cases, but elevated or decreased levels were also described. In a recent study of plasma IGFs and IGFbinding proteins (IGFBPs), we found decreased levels of IGF-II, IGFBP-3 and IGFBP-4 in the circulation of patients clinically suspected of Sotos syndrome (22). However, no data are available on IGFs and IGFBPs in Sotos patients with or without a heterozygous mutation or deletion in the NSD1 gene.

The function of NSD1 has not yet been fully understood. The protein, a transcriptional intermediary factor, may act as either a nuclear receptor co-repressor or co-activator by interacting with the holo- or apoforms respectively, of the ligand-binding domain of different subsets of nuclear hormone receptors (23). It has been postulated that NSD1 acts as a co-repressor of growth promoting genes (4). NSD1 expression in human tissue has been detected in foetal/adult brain, kidney, skeletal muscle, spleen and thymus (24). It is unknown whether NSD1 influences the expression of IGFs and IGFBPs.

In this study patients clinically suspected of Sotos syndrome were divided into a group with heterozygous deletions or mutations in the NSD1 gene (NSD1 ${ }^{+/-}$) and a group with only wild-type alleles $\left(\mathrm{NSD}^{+/+}\right)$. In these two categories of patients we studied systemic levels of IGFs and IGFBPs and the responses of cultured skin fibroblasts to IGFs. Skin fibroblasts express IGF-I and IGF-II receptors and therefore represent a suitable model for studying cellular responses to IGFs and IGFBP-3 expression in growth disorders (25-27). We intended to answer the following questions: (i) do $\mathrm{NSD}^{+/-}$ patients show a distinct pattern of plasma IGF/IGFBP levels, i.e. being different from those of the $\mathrm{NSD}^{+/+}$ subjects and the reference population? and (ii) similarly, do NSD $1^{+/-}$skin fibroblasts respond differently to IGFs in terms of mitogenic response and IGFBP-3 secretion?

\section{Patients and methods}

\section{Patients}

The study was conducted with the prior consent of the Medical Ethical Committee of the Leiden University Medical Center. All subjects or their parents included in the study gave informed consent to participate. Twenty-nine patients clinically suspected of Sotos syndrome were divided in an $\mathrm{NSD}^{+/-}$group and an $\mathrm{NSD}^{+/+}$group based on the results of fluorescence in situ hybridization (FISH) and mutation analysis on blood samples. The NSD1 mutation analysis is described in a separate paper (28). Auxological and clinical characteristics of the patients are shown in Table 1. In one patient a deletion was detected and in 10 patients, including three members of one family, pathogenic mutations were detected. Skin fibroblasts were obtained by punch biopsy of the forearm skin of 23 patients. Skin fibroblasts of 12 normal donors, mean age 10.5 years (range 3.7-17.1 years), three females and nine males, were obtained from the fibroblast bank of the Wilhelmina Children's Hospital, Utrecht, The Netherlands.

\section{Measurements of IGFs and IGFBPs in plasma}

Plasma IGF-I, IGF-II, IGFBP-2, IGFBP-3, IGFBP-4 and IGFBP-6 levels were determined by specific RIAs. For each parameter and the IGF-I/-IGFBP-3 ratio normative range values were available and plasma levels were expressed as SDS. Assays, their validation and normative range values have been described in detail in previously published studies $(22,29-34)$.

Table 1 Characteristics of the patients suspected of Sotos syndrome.

\begin{tabular}{|c|c|c|c|}
\hline & NSD1 ${ }^{+/-}$ & NSD1 ${ }^{+/+}$ & $P$ value \\
\hline Number of blood samples & 11 & 18 & \\
\hline Male/female & $7 / 4$ & $13 / 5$ & 0.63 \\
\hline Mean age (range) in years & $15(2.1-36.3)$ & $14.8(4.6-48.4)$ & 0.98 \\
\hline Mean height SDS corrected for TH SDS $(95 \% \mathrm{Cl})$ & $1.70(1.05-2.36)$ & $0.92(0.27-1.56)$ & 0.1 \\
\hline Mean birth length SDS $(95 \% \mathrm{Cl})$ & $1.18(-0.16-2.51)$ & $0.84(0.14-1.54)$ & 0.59 \\
\hline Mean head circumferences SDS (95\% Cl) & $2.91(1.98-3.83)$ & $2.28(1.47-3.08)$ & 0.39 \\
\hline \multicolumn{4}{|l|}{ Fibroblast experiments } \\
\hline Number of cells lines & 10 & 13 & \\
\hline Male/female & $6 / 4$ & $10 / 3$ & 0.39 \\
\hline Mean age (range) & $16.2(2.1-36.3)$ & $11.3(4.6-36.3)$ & 0.27 \\
\hline
\end{tabular}

$\mathrm{TH}$, target height. 


\section{Cell culture}

Skin fibroblasts were maintained in $9 \mathrm{~cm}$ culture dishes in Dulbecco's modified Eagle's medium (DMEM) supplemented with $10 \%$ ( $\mathrm{vol} / \mathrm{vol}$ ) foetal calf serum (FCS; Gibco BRL), penicillin and streptomycin. The cultures were established in a humidified atmosphere with 5\% (vol/vol) $\mathrm{CO}_{2}$ at $37^{\circ} \mathrm{C}$. The cultures were split (1:4) upon reaching confluence. In all experiments, cells between passages 2 and 15 were used. Cells were counted and seeded at a density of $1.5 \times 10^{4}$ cells $/ \mathrm{ml}$. For $\left[\right.$ methyl $\left.{ }^{3} \mathrm{H}\right]$ thymidine $(84 \mathrm{Ci} / \mathrm{mmol}$; Amersham International) experiments, cells were cultured in either 24-well plates $(0.5 \mathrm{ml} /$ well $)$ or 6 -well plates $(1.5 \mathrm{ml} /$ well $)$, as indicated.

\section{Mitogenic response to IGF-I/IGF-II}

Mitogenic response after treatment of fibroblasts with IGF-I or IGF-II (Pepro Tech, Rocky Hill, NJ, USA) was assessed by the cellular incorporation of [methyl- $\left.{ }^{3} \mathrm{H}\right]$ thymidine. For these experiments cells were cultured in 24-well dishes in DMEM containing $10 \%$ FCS for $48 \mathrm{~h}$. This was followed by incubation in serum-free DMEM containing 0.1\% (wt/vol) BSA for $72 \mathrm{~h}$. Subsequently cells were exposed to DMEM containing $0.1 \%$ BSA with increasing concentrations of IGF-I $(0.3,1,6,10$ and $20 \mathrm{ng} / \mathrm{ml})$ or IGF-II. After $20 \mathrm{~h}$ of incubation, [methyl- ${ }^{3} \mathrm{H}$ ] thymidine was added in a final concentration of $0.5 \mu \mathrm{Ci} / \mathrm{ml}$. After $4 \mathrm{~h}$ the incorporation of $\left[\right.$ methyl- $\left.{ }^{3} \mathrm{H}\right]$ thymidine was terminated by aspirating the medium. Plates were washed twice with $1 \mathrm{ml}$ PBS and once with $0.5 \mathrm{ml} 10 \%$ (vol/vol) trichloric acid. After treatment with $0.5 \mathrm{ml} \mathrm{10 \%} \mathrm{(vol/vol)}$ trichloric acid for $30 \mathrm{~min}$ at $4{ }^{\circ} \mathrm{C}$, cell lysates were solubilized overnight in $0.25 \mathrm{ml} 0.1 \mathrm{M} \mathrm{NaOH}$ and $0.2 \%$ SDS. Aliquots of $250 \mu \mathrm{l}$ in $1 \mathrm{ml}$ instagell $(2+)$ (Packard, Downers Grove, IL, USA) were counted in a Packard 1500-tri-carb-liquid scintillation analyser. Measurements were done in quadruplicate and all experiments were performed at least twice. The mean was calculated from the experiments. Data were expressed as counts per min (c.p.m.).

\section{Analysis of IGFBP-3 release into the medium}

Conditioned media of fibroblasts from Sotos patients and controls were analysed. Cells were cultured in 6-well dishes in DMEM containing 10\% FCS for $48 \mathrm{~h}$. This was followed by incubation in serum-free DMEM containing $0.1 \%$ (wt/vol) BSA for $72 \mathrm{~h}$. Subsequently cells were cultured in DMEM containing 0.1\% BSA with or without IGF-I $(10 \mathrm{ng} / \mathrm{ml})$ for $48 \mathrm{~h}$. Media of each well $(1.5 \mathrm{ml})$ were collected and stored at $-20{ }^{\circ} \mathrm{C}$. Media were concentrated by ultrafiltration with a Centricon Centrifugal Filter Device $(50 \mathrm{~min}$ at $4500 \boldsymbol{g})$. Media were concentrated 10 times and immunoreactive IGFBP-3 levels were measured in duplicate by a specific RIA (32). All experiments were performed twice; means from two experiments are reported. Using Western ligand blotting (with $\left[{ }^{125} \mathrm{I}\right] \mathrm{IGF}-\mathrm{II}$ as a probe) IGFBPs secreted in the culture media were studied (35).

\section{RNA extraction and real-time quantitative RT-PCR}

To quantitate IGFBP-3 mRNA levels, real-time quantitative RT-PCR was performed in triplicate using SybrGreen. First, total RNA was prepared from the fibroblast cultures using RNAzol B followed by cleanup using the RNeasy Mini Kit (Qiagen). RNA was quantified by measuring its absorbance at 260 and $280 \mathrm{~nm}$ (Ultrospec 2000 spectrophotometer; Pharmacia Biotech), and its quality was checked by gel electrophoresis and ethidium bromide staining of the 28 and $18 \mathrm{~S}$ rRNA bands. RNA was reverse transcribed into cDNA using the SuperScript First-Strand Synthesis System for RT-PCR (Gibco BRL). The following primer sets were used for the PCR: IGFBP-3: forward 5'-GGT GTC TGA TCC CAA GTT CC-3' (nucleotides 476-495) and reverse 5'-AGA GGC TGC CCA TAC TTA TCC-3' (795-815); glyceraldehyde-phosphate dehydrogenase (GAPDH): forward 5'-TTA GCA CCC CTG GCC AAG G$3^{\prime}$ (469-487) and reverse 5'-CTT ACT CCT TGG AGG CCA TG-3' (989-1008); $\beta 2$-microglobulin: forward 5'-CCA GCA GAG AAT GGA AAG TC-3' (100-119) and reverse $5^{\prime}$-GAT GCT GCT TAC ATG TCT CG-3' (341-360). All PCR amplicons spanned exon-intron boundaries. The PCRs were performed in the presence of $5 \mu \mathrm{l} \mathrm{Taq}$ Gold buffer, $6 \mu \mathrm{l} 25 \mathrm{mM} \mathrm{MgCl} 2,8 \mu \mathrm{l}$ $1.25 \mathrm{mM}$ dNTPs, $1.25 \mathrm{U}$ Amplitaq Gold DNA polymerase (all from Applied Biosystems, Nieuwekerk ad Ijssel, The Netherlands), $2 \mu \mathrm{l} 10 \mu \mathrm{M}$ stock solution of sense and antisense primers (Eurogentec, Maastricht, The Netherlands), $0.15 \mu \mathrm{l}$ SybrGreen (Molecular Probes, Leiden, The Netherlands) and $0.6 \mu \mathrm{l} 2 \mathrm{ng} / \mu \mathrm{l}$ cDNA in a final volume of $50 \mu \mathrm{l}$. Water was used as a negative control. PCR amplification reactions were performed in an ABI Prism 7700 spectrofluorometric thermal cycler (Applied Biosystems). Fluorescence spectra were recorded and the threshold cycle number $(\mathrm{Ct})$ was calculated with the accompanying software, after checking the specificity of the end products of the PCR by gel electrophoresis. The angle of inclination of the linear part of the amplification curve was identical using the three different primer combinations. For each cell line Ct values for IGFBP-3 were subtracted from the $\mathrm{Ct}$ values of GAPDH or $\beta 2$-microglobulin ( $\Delta \mathrm{Ct}$ values). The mean $\Delta \mathrm{Ct}$ value of an individual sample was based on three independent measurements.

\section{Statistical analysis}

Data were analysed with SPSS for Windows version 10.0. To compare plasma SDS values with the reference 
population a Student's $t$ test was used. Values of IGFBP-3 before and after stimulation of IGF-I were compared with the Wilcoxon signed ranks test. The Mann-Whitney $\mathrm{U}$ test was used to compare all other measurements. $P$ values of $<0.05$ were considered significant.

\section{Results}

\section{Plasma levels of IGFs and IGFBPs}

Mean values of IGF and IGFBP SDS are shown in Table 2. Individual SDS values are shown as scatter plots in Fig. 1. Within the NSD $1^{+/-}$group, no differences were found between the patient with a deletion and the patients with mutations, except for IGFBP-2, which was higher in the former patient. Mean serum levels of IGFs and IGFBPs in the NSD1 ${ }^{+/-}$group differed from the $\mathrm{NSD}^{+/+}$group in most parameters, except in IGFBP-3 and -4 . The largest difference between the $\mathrm{NSD}^{+/-}$group and the NSD $1^{+/+}$group was found for IGFBP-6, which was significantly higher in the first group. The mean values of all IGFs and IGFBPs in the NSD $1^{+/-}$patients differed from the reference values. IGFBP-3 was the only parameter that was significantly decreased in comparison with the reference population in both groups. The IGF-I/IGFBP-3 ratio SDS was significantly elevated in the $\mathrm{NSD}^{+/+}$group (mean $+1.27,95 \%$ confidence interval (CI) $0.42-2.12$ ), whereas for the $\mathrm{NSD}^{+/-}$ group this parameter was within the normal range (mean $-0.31,95 \% \mathrm{CI}-0.88-0.26$ ).

\section{Mitogenic response}

No correlation was found between the age of a particular patient at the moment of skin biopsy and both unstimulated and IGF-stimulated [methyl- $\left.{ }^{3} \mathrm{H}\right]$ thymidine incorporation by the cultured fibroblasts. In a series of pilot experiments, a dose-response curve of two NSD $1^{+/-}$and three control cultures clearly revealed a decreased sensitivity to IGF-I in NSD1 ${ }^{+/-}$fibroblasts (mean $\mathrm{ED}_{50}$ : $\mathrm{NSD}^{+-}$cells, $10.8 \mathrm{ng} / \mathrm{ml}$; control cells, $3.2 \mathrm{ng} / \mathrm{ml}$; data not shown). Subsequently, the responses to $10 \mathrm{ng} / \mathrm{ml}$ IGFs I and II were studied in all fibroblast cultures. Mean values of basal and

Table 2 Plasma IGF and IGFBP values expressed as mean SDS $(95 \% \mathrm{Cl})$; comparison between patients with and without an NSD1 gene alteration and comparison with reference population.

\begin{tabular}{lcrr}
\hline & NSD1 $^{+/-}(n=11)$ & NSD1 $^{+/+}(n=18)$ & $\boldsymbol{P}$ value \\
\hline IGF-I & $-1.2(-2.3-0.2)^{\star}$ & $0(-0.7-0.7)$ & 0.036 \\
IGF-II & $-1.2(-1.8-0.7)^{\star *}$ & $-0.2(-0.8-0.4)$ & 0.019 \\
IGFBP-2 & $0.8(0-1.6)^{\star}$ & $-0.2(-0.9-0.5)$ & 0.049 \\
IGFBP-3 & $-1.7(-2.7-0.8)^{\star *}$ & $-1.3(-2-0.6)^{* *}$ & 0.413 \\
IGFBP-4 & $-0.4(-0.7-0.1)^{\star *}$ & $-0.5(-0.6-1.5)$ & 0.157 \\
IGFBP-6 & $1.5(0.9-2.2)^{\star *}$ & $0(-0.4-0.3)$ & $<0.001$ \\
\hline
\end{tabular}

${ }^{\star} P \leq 0.05$ compared with reference population; ${ }^{\star \star} P<0.01$ compared with reference population.
IGF-I- and IGF-II-stimulated rates of [methyl- $\left.{ }^{3} \mathrm{H}\right]$ thymidine incorporation are depicted in a bar chart (Fig. 2). Basal values of $\left[\right.$ methyl $\left.-{ }^{3} \mathrm{H}\right]$ thymidine incorporation by $\mathrm{NSD}^{+/-}$cells were lower compared with those for $\mathrm{NSD}^{+/+}$fibroblasts $(P=0.02)$, but the difference with controls did not reach significance $(P=0.07)$. Both IGF-I and IGF-II stimulated growth of $\mathrm{NSD}^{+/-}$ fibroblast cultures was less pronounced than encountered for either $\mathrm{NSD}^{+/+}(P<0.001, P=0.02)$ or control $(P=0.04)$ cells. No differences were found between fibroblasts from the patient with an NSD1 deletion and cells derived from patients with an NSD1 mutation.

\section{IGFBP-3 secretion}

Western ligand blots with labelled IGF-II of the media of six NSD $1^{+/-}$fibroblasts and eight controls showed no significant differences in IGFBP patterns between $\mathrm{NSD}^{+/-}$and controls (data not shown). Only overall levels of IGFBP-3 tended to be higher in NSD $1^{+/-}$fibroblasts. To substantiate this observation IGFBP-3 secretion in medium was quantified by RIA. For each of the three groups no significant increase of IGFBP-3 secretion was detected after stimulation with IGF-I (controls, $P=0.65 ; \mathrm{NSD}^{+/+}, P=0.35 ; \mathrm{NSD}^{+/-}$, $P=0.13)$. No significant differences were found between the three groups of fibroblasts for IGFBP-3 secretion, but a trend of higher IGFBP-3 secretion was detected in the NSD1 $1^{+/-}$cell lines in comparison with controls (basal, $P=0.17$; after IGF-I, $P=0.09$ ) as shown in Fig. 3.

\section{IGFBP-3 mRNA expression}

Expression levels of IGFBP-3 mRNA by the $\mathrm{NSD}^{+/-}$ and control fibroblasts were compared. The mean difference in $\mathrm{Ct}$ between the two groups was 1.9 when corrected for GAPDH and 2.3 when corrected for $\beta 2$-microglobulin. This corresponds to approximately 3.5-5-fold more IGFBP-3 mRNA in NSD1 ${ }^{+/-}$fibroblasts than in controls. A representative amplification curve of pooled cDNA derived from $\mathrm{NSD}^{+/-}$and of control fibroblasts using IGFBP-3 primers is shown in Fig. 4.

\section{Discussion}

In this study, we show for the first time that several parameters of the IGF system in Sotos patients, harbouring a heterozygous mutation or deletion of the NSD1 gene, differ from those in patients clinically suspected of Sotos syndrome who have two normal NSD1 alleles, and the reference population.

Based on the essential role of IGF-I in intrauterine and postnatal growth we postulated that NSD1 mutations would result in increased IGF-I bioactivity, 

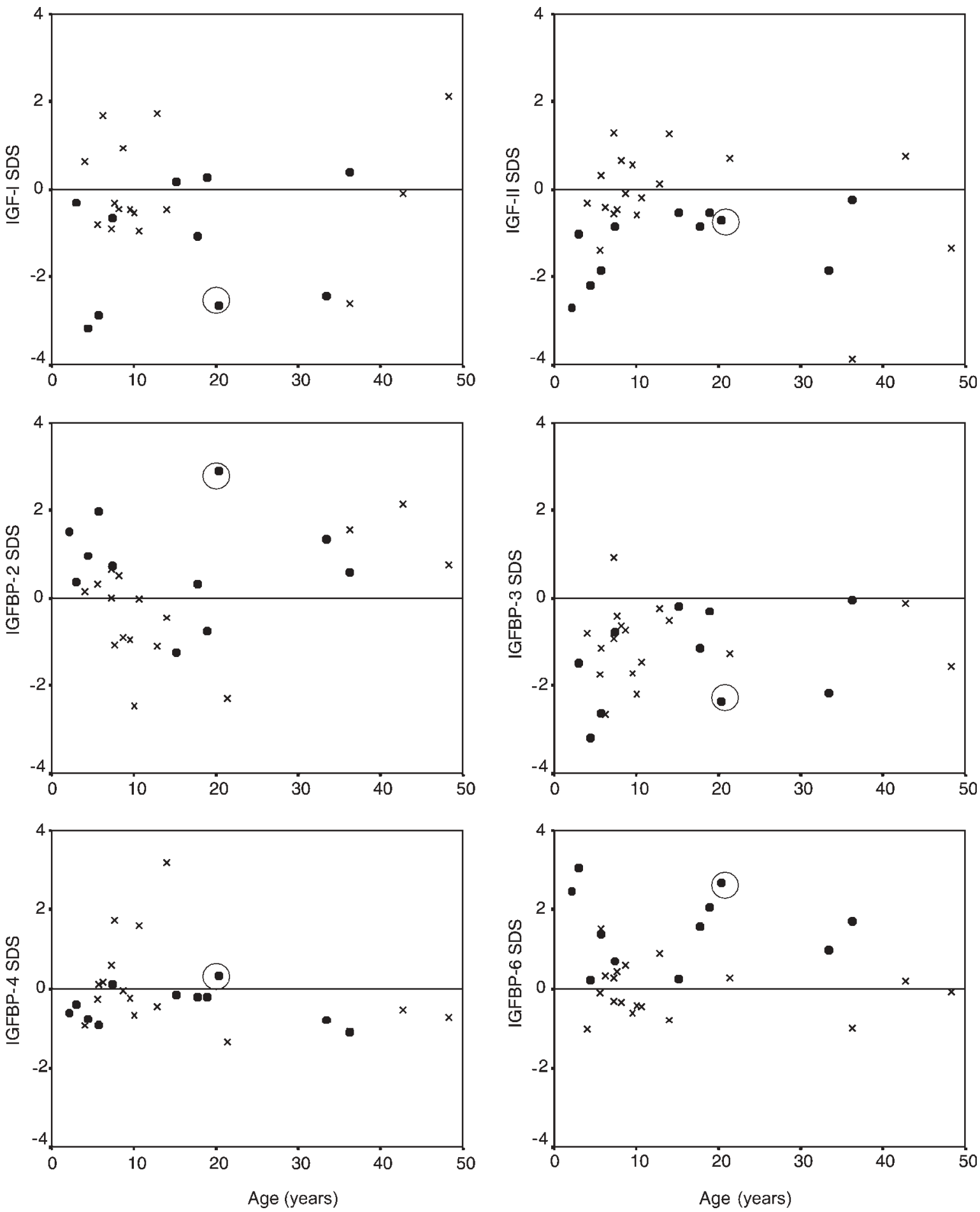

Figure 1 Scatter plots of the individual SD scores of plasma IGF and IGFBP levels of patients suspected of Sotos syndrome with and without an aberrant NSD1 gene. Three outliers did not fit in the plots: IGFBP-3: NSD1 ${ }^{+/-} 2.1$ years, -4.6 SDS; NSD1 ${ }^{+/+} 36.3$ years,

-5.4 SDS; IGFBP-4: NSD1 ${ }^{+/+} 8.2$ years, +6.7 SDS. The encircled dots depict the values of the patient with a deletion of the NSD1 gene. $\mathrm{NSD}^{+/-}, \times \mathrm{NSD}^{+/+}$.

leading to overgrowth in Sotos syndrome. Additional support for this hypothesis comes from a patient with three copies of the IGF-IR (13), who exhibits a Sotos-like phenotype, suggesting that overactivation of the IGF-IR can indeed provide an explanation for the overgrowth observed in Sotos syndrome. However our studies did not show evidence for increased IGF-I bioactivity in serum, nor for increased responsiveness 


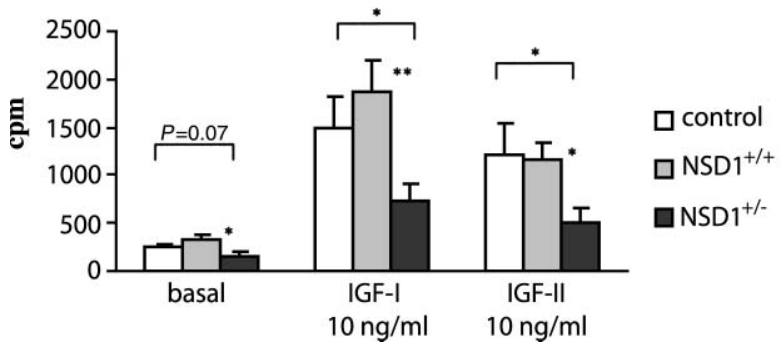

Figure 2 [methyl- ${ }^{3} \mathrm{H}$ ]Thymidine incorporation into DNA, under basal conditions (no IGF) and in response to IGF-I or IGF-II $(10 \mathrm{ng} / \mathrm{ml})$. Fibroblast cultures of 12 control, $9 \mathrm{NSD} 1^{+/-}$patients and $13 \mathrm{NSD}^{+/+}$patients were used. Results are plotted as counts per min (c.p.m.; mean + S.E.M.); ${ }^{\star} P<0.05$, ${ }^{*} P<0.01$. Basal proliferation: control $247 \pm 31$ c.p.m., NSD1 ${ }^{+/+} 325 \pm 57$ c.p.m., NSD1 ${ }^{+/-} 159 \pm 34$ c.p.m.; IGF-I: control $1502 \pm 327$ c.p.m., $\mathrm{NSD}^{+/+} 1873 \pm 336$ c.p.m., NSD $1^{+/-} 728 \pm 169$ c.p.m.; IGF-II: control $1205 \pm 346$ c.p.m., NSD $1^{+/+} 1152 \pm 196$ c.p.m., NSD $1^{+-}$ $508 \pm 150$ c.p.m.

of the IGF-IR in fibroblasts of $\mathrm{NSD} 1^{+/-}$patients. Instead, serum values of IGF-I, IGF-II, IGFBP-3 and IGFBP-4 were decreased and IGFBP-2 and IGFBP-6, generally considered as inhibitors of IGF bioactivity (36), were increased compared with the reference population. In addition, the IGF-I/IGFBP-3 ratio was normal. Furthermore, skin fibroblasts of $\mathrm{NSD}^{+/-}$ patients had a reduced mitogenic response both under basal conditions and after IGF-I stimulation when compared with cells derived from $\mathrm{NSD}^{+/+}$patients and

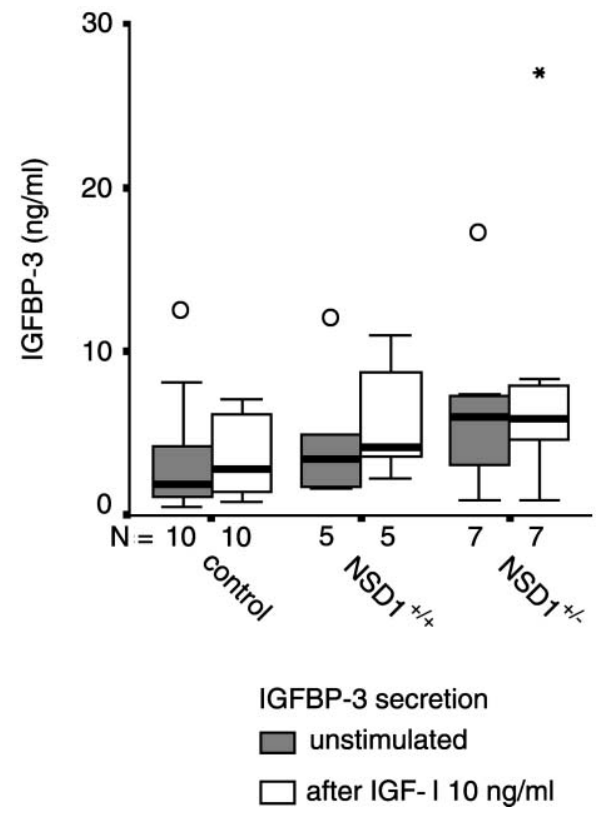

Figure 3 IGFBP-3 secretion into the media by control, NSD1 ${ }^{+/+}$ and NSD1 $1^{+/-}$fibroblasts under basal conditions and after stimulation with IGF-I (10 ng/ml) as determined by RIA. Values are shown as box plots (the box represents the 25th and 75th percentiles, the bars the 5th and 95th percentiles, $\bigcirc$ and * the outliers and extremes). Differences were not significant $(P=0.09)$, although NSD $1^{+1-}$ cells tended to produce more IGFBP-3 than control fibroblasts.

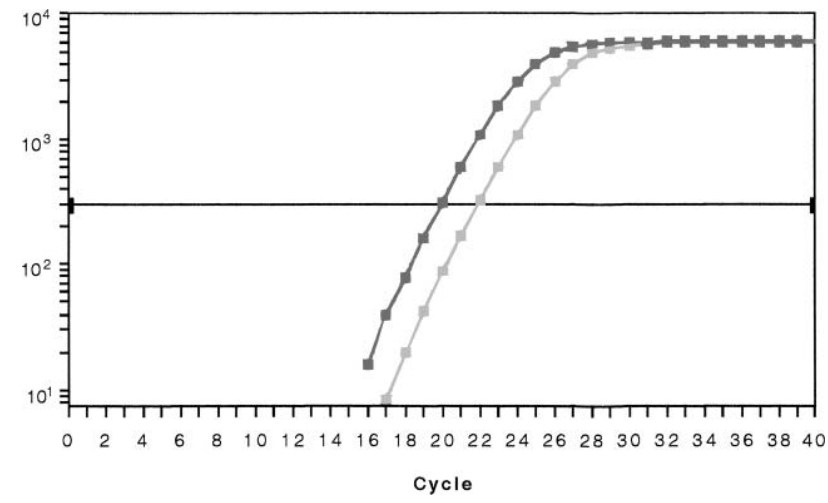

Figure 4 Real-time quantitative RT-PCR. Amplification curve of pooled cDNA derived from NSD $1^{+/-}$(left-hand curve, dark grey) and control fibroblasts (right-hand curve, light grey) using IGFBP-3 primers.

controls (only after IGF-I stimulation) and they express more IGFBP-3 mRNA than controls.

In the past limited reports on the expression of components of the IGF/IGFBP family in Sotos syndrome have appeared in the literature, but the results were not related to the presence or absence of NSD1 mutations. The studies were inconclusive concerning somatomedin activity or IGF-I values. Normal values have been reported, but so have elevated or decreased levels $(2,16,18-21)$. Remarkably, the $\mathrm{NSD}^{+/-}$ group is distinguishable from the $\mathrm{NSD}^{+/+}$group as well as from other patient groups with growth disorders based on the serum levels of IGFs and IGFBPs. For example, in constitutionally tall children normal IGF-I values, high IGF-II values and an increased IGF/IGFBP ratio have been described (37) and in subjects with intrauterine growth retardation low IGF-I levels and normal IGF-II levels have been reported (38). NSD1 ${ }^{+/+}$patients, who were Sotoslike clinically, resemble the reference population in all studied endocrine and paracrine parameters, except for lower IGFBP-3 values and a higher IGF-I/IGFBP-3 ratio. Although we cannot completely rule out that some of these patients may have an aberrant NSD1 gene not detected by the mutation screening (e.g. splicing variants due to deletions or mutations in introns or mutations in the promoter region of NSD1), our data are strongly suggestive for a non-NSD1-related growth disorder with Sotos-like features in the majority of these patients. These patients differ from constitutionally tall patients by the absence of elevated serum IGF-II levels, but have in common an increased IGF/IGFBP ratio. This suggests that an increase in bioavailability of IGFs in these patients may at least partly contribute to the overgrowth phenotype.

A striking finding was that plasma levels of IGFBP-2 and especially IGFBP- 6 in NSD $1^{+/-}$patients were elevated. Both IGFBP-2 and IGFBP-6 have a higher affinity for IGF-II than for IGF-I and are therefore thought to 
inhibit IGF-II bioactivity preferentially $(39,40)$. IGFBP2 and IGFBP- 6 are the two major binding proteins present in cerebrospinal fluid and are locally produced in the central nervous system. Developmental delay as well as increased head circumference is a characteristic finding in Sotos syndrome.

We found a diminished basal proliferative activity and a diminished response to IGF-I and IGF-II by $\mathrm{NSD}^{+/-}$fibroblasts. These findings are in contrast to observations in fibroblasts of a Sotos-like patient with tall stature and an enhanced expression of the IGF-IR (13). Altered expression of the IGF-IR is therefore unlikely to play a key role in the aetiology of Sotos syndrome. IGFBP-3 is the most abundant IGFBP secreted by human fibroblasts (41). A trend of higher secretion of this IGFBP after stimulation with IGF-I was found for $\mathrm{NSD1}^{+/-}$fibroblasts compared with controls. Also a higher IGFBP-3 mRNA expression was found. IGFBP3 can inhibit IGF effects by competing for binding with their specific receptors (42). Elevated secretion of this peptide has been found for fibroblasts of patients with idiopathic short stature (ISS) (26) and Turner syndrome (27), indicating that this phenomenon is seen in distinct growth disorders characterized by tall as well as short stature.

How do the modest endocrine and paracrine changes in the IGF system relate to NSD1 gene aberrations? It is postulated that NSD1 encodes a protein that can act both as a co-repressor and activator of a subset of nuclear hormone receptors for growth-promoting genes (i.e. the thyroid hormone receptor, the oestrogen receptor and the retinoic acid receptor) through interaction with the ligand-binding domain in the presence or absence of the ligand respectively $(4,43-45)$. In a knockout mouse model, NSD1 has been shown to be important for post-implantation development (46). Homozygous NSD1 mutant mice were severely growth retarded, showed a high incidence of apoptosis and died before day 10.5 in utero. Mice heterozygous for an NSD1 mutation were viable and showed normal growth apparently lacking the typical features of Sotos syndrome. It is presently unclear whether these mice represent a suitable animal model for Sotos syndrome. Although detailed studies are currently lacking, there are some indications that the receptors for oestrogen and retinoic acid are involved in the regulation of transcription of IGF-I, IGF-II, IGFBP-3 and IGFBP-6 (47-50). Of particular interest is the presence of a functional retinoic acid-response elements in the IGFBP-6 promoter suggesting that elevated IGFBP-6 serum levels in $\mathrm{NSD}^{+/-}$patients could be due to alterations in retinoic acid-mediated gene transcription of the IGFBP-6 promoter. The endocrine and paracrine aberrations in the IGF-I system of $\mathrm{NSD1}^{+/-}$Sotos patients may therefore be a direct consequence of disturbed gene transcription by nuclear hormone receptors. In this respect it is noteworthy to mention that
IGFBP-3 can accumulate in the nucleus where it can interact with the retinoid X receptor $\alpha(\operatorname{RXR} \alpha)$. This interaction can modulate retinoidmediated gene transcription and apoptosis in an IGF-I-independent manner $(51-53)$. Whether NSD1 and IGFBP-3 compete for binding to $\mathrm{RXR} \alpha$ is presently unclear. However, the increased IGFBP-3 mRNA expression in $\mathrm{NSD}^{+/-}$fibroblasts may also contribute to disturbed nuclear hormone signalling via retinoids.

The relation between the alterations in the IGF/IGFBP family and overgrowth are less clear. In fact, the observed aberrations would be more in line with short stature (low IGFs, high inhibitory IGFBPs, blunted mitogenic response to IGF-I) rather than with tall stature. It could be that the impact of NSD1 haploinsufficiency on the expression of IGFs and IGFBPs varies between organs, resulting in tissue-specific changes in availability of bioactive IGF-I. In this respect, the effect of $\mathrm{NSD}^{+/-}$exerted on the growth plate is relevant. NSD1 is expressed by chondrocytes in the human growth plate (M Karperien, unpublished observations) and may affect the equilibrium in the IGF system favouring increased proliferation at the tissue level. Animal studies have shown that chondrocytes express IGFBPs 2-6 (54). Alternatively, the observed endoand paracrine changes may be the result of a compensatory physiological reaction of the body to decelerate the increased growth induced by NSD1 aberrations. In that case, NSD1 haploinsufficiency would induce overgrowth by processes being largely independent of the IGF system. However, then one should expect that fibroblasts of $\mathrm{NSD}^{+/-}$patients have a higher intrinsic proliferative capacity compared to controls. Our data do not support such a phenomenon.

In conclusion, NSD1 gene mutations in Sotos patients are reflected in modest endocrine and paracrine alterations in the IGF/IGFBP system. Based on these alterations, the group of Sotos patients with $\mathrm{NSD}^{+/-}$can be distinguished from the NSD1 ${ }^{+/+}$subjects, the reference population as well as from patients with other growth disorders. The mechanism by which NSD1 gene mutations induce overgrowth and the involvement of the IGF system in this process requires further study.

\section{Acknowledgements}

We would like to thank the patients and their families for participating in the study, Saskia le Cessie for statistical advice, Niels van Lelyveld for his help with the Western ligand blotting, Sylvia van Buul-Offers for her help and comments and STINAFO and LUMC for their financial support. This work was supported by the 'Dutch fund for disabled children' (STINAFO) and the Leiden University Medical Center. 


\section{References}

1 Sotos JF, Dodge PR, Muirhead D, Crawford JD \& Talbot NB. Cerebral gigantism in childhood. A syndrome of excessively rapid growth with acromegalic features and a nonprogressive neurologic disorder. New England Journal of Medicine 1964271 109-116.

2 Wit JM, Beemer FA, Barth PG, Oorthuys JW, Dijkstra PF, Van den Brande JL \& Leschot NJ. Cerebral gigantism (Sotos syndrome). Compiled data of 22 cases. Analysis of clinical features, growth and plasma somatomedin. European Journal of Pediatrics 1985 $144131-140$.

3 Cole TR \& Hughes HE. Sotos syndrome: a study of the diagnostic criteria and natural history. Journal of Medical Genetics 199431 $20-32$.

4 Kurotaki N, Imaizumi K, Harada N, Masuno M, Kondoh T \& Nagai T. Haploinsufficiency of NSD1 causes Sotos syndrome. Nature Genetics 200330 365-366.

5 Douglas J, Hanks S, Temple IK, Davies S, Murray A, Upadhyaya M et al. NSD1 mutations are the major cause of Sotos syndrome and occur in some cases of Weaver syndrome but are rare in other overgrowth phenotypes. American Journal of Human Genetics $200372132-143$.

6 Rio M, Clech L, Amiel J, Faivre L, Lyonnet S, Le Merrer M et al. Spectrum of NSD1 mutations in Sotos and Weaver syndromes. Journal of Medical Genetics $2003 \mathbf{4 0} 436$-440.

7 Turkmen S, Gillessen-Kaesbach G, Meinecke P, Albrecht B, Neumann LM, Hesse V et al. Mutations in NSD1 are responsible for Sotos syndrome, but are not a frequent finding in other overgrowth phenotypes. European Journal of Human Genetics 200311 858-865.

8 Le Roith D, Bondy C, Yakar S, Liu JL \& Butler A. The somatomedin hypothesis: 2001. Endocrine Reviews 200122 53-74.

9 Yakar S, Rosen CJ, Beamer WG, Ackert-Bicknell CL, Wu Y, Liu JL et al. Circulating levels of IGF-1 directly regulate bone growth and density. Journal of Clinical Investigations $2002 \mathbf{1 1 0}$ $771-781$.

10 Baker J, Liu JP, Robertson EJ \& Efstratiadis A. Role of insulin-like growth factors in embryonic and postnatal growth. Cell 1993 $7573-82$

11 Liu JP, Baker J, Perkins AS, Robertson EJ \& Efstratiadis A. Mice carrying null mutations of the genes encoding insulin-like growth factor I (Igf-1) and type 1 IGF receptor (Igflr). Cell $19937559-72$.

12 Woods KA, Camacho-Hubner C, Savage MO \& Clark AJ. Intrauterine growth retardation and postnatal growth failure associated with deletion of the insulin-like growth factor I gene. New England Journal of Medicine 1996335 1363-1367.

13 Okubo Y, Siddle K, Firth H, O'Rahilly S, Wilson LC, Willatt L et al. Cell proliferation activities on skin fibroblasts from a short child with absence of one copy of the type 1 insulin-like growth factor receptor (IGF1R) gene and a tall child with three copies of the IGF1R gene. Journal of Clinical Endocrinology and Metabolism $2003885981-5988$.

14 Ambler GR, Cowell CT, Quigley CA \& Silink M. Growth hormone hypersecretion in Sotos' syndrome? Acta Paediatrica 199382 214-216.

15 Ranke MB \& Bierich JR. Cerebral gigantism of hypothalamic origin. European Journal of Pediatrics $1983140109-111$.

16 Saenger P, Levine LS, Wiedemann E, Schwartz E \& New MI. Letter: Somatomedin in cerebral gigantism. Journal of Pediatrics $1976 \mathbf{8 8}$ 155-156.

17 Sakano T, Yoshimitsu T, Tanabe A, Tanaka T, Kobayashi Y, Usui T \& Takano K. Cerebral gigantism: a report of two cases with elevated serum somatomedin A levels and a review of the Japanese literature. Hiroshima Journal of Medical Sciences $1977 \mathbf{2 6}$ $311-319$.

18 Goumy P, Malpuech G, Gannat M \& Menut G. Familial cerebral gigantism. A new case with autosomal dominant transmission? Pediatrie $197934249-256$.
19 Hansen FJ \& Friis B. Familial occurrence of cerebral gigantism. Sotos' syndrome. Acta Paediatrica Scandinavica 197665387 -389.

20 Lecornu M. The serum level of sulfatation factor (somatomedine) in growth retardations, cerebral gigantism and acromegaly. Archives Francaises de Pediatrie 197330 595-608.

21 Lecornu M, Fonlupt J, Jezequel C \& Coutel Y. Cerebral gigantism in twins. Archives Francaises de Pediatrie 197633 277-285.

22 de Boer L, Hoogerbrugge CM, van Doorn J, van Buul-Offers SC, Karperien M \& Wit JM. Plasma insulin-like growth factors (IGFs), IGF-binding proteins (IGFBPs), acid-labile subunit (ALS) and IGFBP-3 proteolysis in individuals with clinical characteristics of Sotos syndrome. Journal of Pediatric Endocrinology $\mathcal{E}$ Metabolism 200417 615-627.

23 Huang N, vom BE, Garnier JM, Lerouge T, Vonesch JL, Lutz Y et al. Two distinct nuclear receptor interaction domains in NSD1, a novel SET protein that exhibits characteristics of both corepressors and coactivators. EMBO Journal 199817 3398-3412.

24 Kurotaki N, Harada N, Yoshiura K, Sugano S, Niikawa N \& Matsumoto N. Molecular characterization of NSD1, a human homologue of the mouse Nsd1 gene. Gene 2001279 197-204.

25 Freeth JS, Ayling RM, Whatmore AJ, Towner P, Price DA, Norman MR \& Clayton PE. Human skin fibroblasts as a model of growth hormone $(\mathrm{GH})$ action in GH receptor-positive Laron's syndrome. Endocrinology 1997138 55-61.

26 Kamp GA, Ouwens DM, Hoogerbrugge CM, Zwinderman AH, Maassen JA \& Wit JM. Skin fibroblasts of children with idiopathic short stature show an increased mitogenic response to IGF-I and secrete more IGFBP-3. Clinical Endocrinology $2002 \mathbf{5 6}$ 439-447.

27 Barreca A, Larizza D, Damonte G, Arvigo M, Ponzani P Cesarone A et al. Insulin-like growth factors (IGF-I and IGFII) and IGF-binding protein-3 production by fibroblasts of patients with Turner's syndrome in culture. Journal of Clinical Endocrinology and Metabolism 199782 1041-1046.

28 de Boer L, Kant SG, Karparien M, van Beers L, Tjon J, Vink GR, van Tol D, Dauwerse H, le Cessie S, Beemer FA, van der Burgt I, Hamel BCJ, Hennekam RC, Kuhnle U, Mathijssen IB, VeenstraKnol HE, Schrander Stumpel CT, Breuning MH \& Wit JM. Genotype-phenotype correlation in patients suspected of having Sotos syndrome. Hormone Research (In Press).

29 de Vries BB, Robinson H, Stolte-Dijkstra I, Tjon Pian Gi CV, Dijkstra PF, van Doorn J et al. General overgrowth in the fragile X syndrome: variability in the phenotypic expression of the FMR1 gene mutation. Journal of Medical Genetics 199532 764-769.

30 Hokken-Koelega AC, Hackeng WH, Stijnen T, Wit JM, Muinck Keizer-Schrama SM \& Drop SL. Twenty-four-hour plasma growth hormone $(\mathrm{GH})$ profiles, urinary $\mathrm{GH}$ excretion, and plasma insulin-like growth factor-I and -II levels in prepubertal children with chronic renal insufficiency and severe growth retardation. Journal of Clinical Endocrinology and Metabolism 199071 688-695.

31 Juul A, Bernasconi S, Chatelain P, Hindmarsh P, Hochberg Z, Hokkenkoelega A et al. Diagnosis of growth hormone $(\mathrm{GH})$ deficiency and the use of $\mathrm{GH}$ in children with growth disorders. Hormone Research $199951284-299$.

32 Rikken B, van Doorn J, Ringeling A, Van den Brande JL, Massa G \& Wit JM. Plasma levels of insulin-like growth factor (IGF)-I, IGF-II and IGF- binding protein-3 in the evaluation of childhood growth hormone deficiency. Hormone Research 199850 166-176.

33 van Doorn J, Ringeling AM, Shmueli SS, Kuijpers MC, HokkenKoelega AC, Buul-Offers SC \& Jansen M. Circulating levels of human insulin-like growth factor binding protein- 6 (IGFBP-6) in health and disease as determined by radioimmunoassay. Clinical Endocrinology $199950601-609$.

34 van Doorn J, Cornelissen AJ \& Buul-Offers SC. Plasma levels of insulin-like growth factor binding protein-4 (IGFBP-4) under normal and pathological conditions. Clinical Endocrinology 2001 54 655-664.

35 Buul-Offers SC, Reijnen-Gresnigt MG, Hoogerbrugge CM, Bloemen RJ, Kuper CF \& Van den Brande JL. Recombinant insulin-like growth factor-II inhibits the growth-stimulating 
effect of growth hormone on the liver of Snell dwarf mice. Endocrinology $1994135977-985$.

36 Rajaram S, Baylink DJ \& Mohan S. Insulin-like growth factorbinding proteins in serum and other biological fluids: regulation and functions. Endocrine Reviews 199718 801-831.

37 Garrone S, Radetti G, Sidoti M, Bozzola M, Minuto F \& Barreca A. Increased insulin-like growth factor (IGF)-II and IGF/IGF-binding protein ratio in prepubertal constitutionally tall children. Journal of Clinical Endocrinology and Metabolism 200287 5455-5460.

38 Lassarre C, Hardouin S, Daffos F, Forestier F, Frankenne F \& Binoux M. Serum insulin-like growth factors and insulin-like growth factor binding proteins in the human fetus. Relationships with growth in normal subjects and in subjects with intrauterine growth retardation. Pediatric Research 199129 219-225.

39 Rechler M \& Clemmons DR. Regulatory actions of insulin-like growth factor-binding proteins. Trends in Endocrinology and Metabolism 19989 176-183.

40 Schneider MR, Lahm H, Wu M, Hoeflich A \& Wolf E. Transgenic mouse models for studying the functions of insulin-like growth factor-binding proteins. FASEB Journal 2000 14 629-640.

41 Camacho-Hubner C, Busby WH Jr, McCusker RH, Wright G \& Clemmons DR. Identification of the forms of insulin-like growth factor-binding proteins produced by human fibroblasts and the mechanisms that regulate their secretion. Journal of Biological Chemistry 1992267 11949-11956.

42 Jones JI \& Clemmons DR. Insulin-like growth factors and their binding proteins: biological actions. Endocrine Reviews 199516 $3-34$.

43 Lee H \& Yen PM. Recent advances in understanding thyroid hormone receptor coregulators. Journal of Biomedical Science 19996 $71-78$.

44 Smith EP, Boyd J, Frank GR, Takahashi H, Cohen RM, Specker B et al. Estrogen resistance caused by a mutation in the estrogenreceptor gene in a man. New England Journal of Medicine 1994 331 1056-1061.

45 Weston AD, Hoffman LM \& Underhill TM. Revisiting the role of retinoid signaling in skeletal development. Birth Defects Research Part C: Embryo Today 200369 156-173.

46 Rayasam GV, Wendling O, Angrand PO, Mark M, Niederreither K, Song L et al. NSD1 is essential for early post-implantation development and has a catalytically active SET domain. EMBO Journal 200322 3153-3163.

47 Fournier B, Gutzwiller S, Dittmar T, Matthias G, Steenbergh P \& Matthias P. Estrogen receptor (ER)-alpha, but not ER-beta, mediates regulation of the insulin-like growth factor I gene by antiestrogens. Journal of Biological Chemistry $200127635444-35449$.

48 Dailly YP, Zhou Y, Linkhart TA, Baylink DJ \& Strong DD. Structure and characterization of the human insulin-like growth factor binding protein (IGFBP)-6 promoter: identification of a functional retinoid response element. Biochimica et Biophysica Acta 2001 $1518145-151$.

49 Gabbitas B \& Canalis E. Retinoic acid stimulates the transcription of insulin-like growth factor binding protein-6 in skeletal cells. Journal of Cellular Physiology $1996 \mathbf{1 6 9} 15-22$.

50 Han GR, Dohi DF, Lee HY, Rajah R, Walsh GL, Hong WK et al. Alltrans-retinoic acid increases transforming growth factor-beta2 and insulin-like growth factor binding protein-3 expression through a retinoic acid receptor-alpha-dependent signaling pathway. Journal of Biological Chemistry 1997272 13711-13716.

51 Schedlich LJ, O'Han MK, Leong GM \& Baxter RC. Insulin-like growth factor binding protein-3 prevents retinoid receptor heterodimerization: implications for retinoic acid-sensitivity in human breast cancer cells. Biochemical and Biophysical Research Communications $200431483-88$.

52 Lee KW \& Cohen P. Nuclear effects: unexpected intracellular actions of insulin-like growth factor binding protein-3. Journal of Endocrinology 2002175 33-40.

53 Liu B, Lee HY, Weinzimer SA, Powell DR, Clifford JL, Kurie JM \& Cohen P. Direct functional interactions between insulin-like growth factor-binding protein-3 and retinoid X receptor-alpha regulate transcriptional signaling and apoptosis. Journal of Biological Chemistry $200027533607-33613$.

54 De Los RP \& Hill DJ. Expression and release of insulin-like growth factor binding proteins in isolated epiphyseal growth plate chondrocytes from the ovine fetus. Journal of Cellular Physiology 2000 $183172-181$.

Received 10 March 2004

Accepted 10 June 2004 